\title{
ROSEMARY RADFORD RUETHER: THEMES FROM A FEMINIST LIBERATION STORY
}

\author{
Denise Ackermann \\ Faculty of Theology \\ Stellenbosch University
}

\begin{abstract}
As one of the earliest and most influential feminist liberation theologians, Rosemary Radford Ruether's oeuvre has enabled many women theologians in different contexts and cultures to cover new ground by drawing on her insights. This article is a tribute to her ground-breaking work and her far ranging interests, all under girded by her passion for justice. In order to tell aspects of her theological story, three themes are dealt with: Feminist theology according to Ruether, feminist theological methodology, and church and ministry. In conclusion, a brief assessment of her work is made with particular reference to the categories of experience, the prophetic-liberating tradition and issues of gender race and ecumenism.
\end{abstract}

Key Words: Rosemary Radford Ruether, Feminist theology, Ministry

\section{Introducing Ruether}

It is impossible to do justice to the creative and versatile mind of Rosemary Radford Ruether in thirty-five minutes when her writings fill almost an entire shelf in my study. Her output is prodigious, her interests catholic. She has authored and edited some thirty-six books and over 600 articles. Her work is astonishing for its depth, quantity and range. Courses on Feminist Theology, Eco-feminism, Anti-Semitism, Jewish/Palestinian relations, Third World feminisms, and Christian church history could be designed by simply using her writings as course material.

Yet Ruether is no intellectual butterfly. Running throughout her work is one constant theme: The claim for justice for those who experience oppression and discrimination, particularly women. In her own words: "Basically I don't like injustice and I don't like to see religion used to justify injustice and oppression." Whether she inveighs against antiSemitism or is a voice for the Palestinians today, ${ }^{2}$ whether she writes on women in the history of Christianity or on the environment, ${ }^{3}$ whether she tackles the lot of the modern family or the divine feminine, whether she reflects on Mary the mother of Jesus or on Christology ${ }^{4}-$ her abiding concern is for justice and the ultimate wholeness of the human race.

Born in 1936 in Georgetown, Texas to a Roman Catholic mother and an Episcopalian father, she has described her upbringing as humanist and free-thinking. Her doctorate is in classics and patristics ${ }^{5}$ and for twenty-five years she taught at Garrett-Evangelical Theological Seminary, an affiliate of North Western University outside Chicago. On retirement, she and her political scientist spouse Herman moved to California where she was first

Hinton 2006:29

See Ruether 1989.

See Ruether 1992.

See Ruether 1985b

Ruether's doctoral dissertation on the life and thought of St Gregory of Nazianzus was published in 1969 by Oxford University Press. 
professor of Feminist Theology at the Pacific School of Religion and the Graduate Theological Union, and is now a visiting professor in Feminist Theology at the Claremont School of Theology. Over a long career spanning more than thirty years she has been a pioneer in the area of feminist theology, an activist in the Civil Rights Movement in the United States of America, and - in the liberation mould - an outspoken social critic of her own country's involvement in wars in Vietnam, Latin America and now in Iraq.

I first encountered her writing in the very early eighties. Ruether, together with Letty Russell, ${ }^{6}$ Beverly Harrison ${ }^{7}$ and later Elisabeth Schüssler Fiorenza, ${ }^{8}$ laid the basis for what was to become a challenging and life-changing discipline for countless women across the world. I do not want to discount the initial work of Mary Daly whose The Church and the Second Sex and Beyond God the Father predated the work of these women. Daly undoubtedly asked the first important question for feminist theologians: "Why do Christian traditions and practices conspire together to oppress women and to accord them second class status in the church?" "In an Autobiographical Preface to the 1975 edition of The Church and the Second Sex, Daly remarked: "Several women-light years have separated me from The Church and the Second Sex, whose author I sometimes have trouble recalling". As a post-Christian philosopher, Daly has repudiated most of what she wrote in those early works. I am not aware that either Russell or Ruether, Harrison or Schüssler Fiorenza, have repudiated their early writings or that they would describe themselves as post-Christian. Radical critics of their respective churches, yes, but still redoubtable theologians contributing to the ever widening scope of Christian theologies. This paper is an all too brief tribute to what Ruether's work has meant to me over the years. She has been my teacher. But, as a strategy born of necessity - given her prodigious output - I am only able to touch on a few topics: Doing feminist theology, feminist theological methodology, and church and ministry. These, I trust, will contribute to understanding Ruether's groundbreaking contribution to the story of feminist liberation theologies.

\section{Feminist Theology according to Ruether}

In her groundbreaking work Sexism and God-talk, Ruether subjects the major Christian doctrines such as God, cosmology, anthropology, Christology, sin, and eschatology, to a radical iconoclastic critique. This work was the first systematic assessment of Christian theology from a feminist theological point of view. Startling for its comprehensiveness when it first appeared, it is a work that still inspires today as scholars delve into its riches. Its systematic approach provides a multi-pronged entry into feminist theological thought and its scrupulous scholarship has stood the test of time.

Not surprisingly it begins with a midrash" ${ }^{10}$ entitled "The kenosis of the Father: A feminist midrash on the Gospel in three acts". Ruether's midrash is an act of imagination that takes the reader to the heart of her book. Racy and humorous, yet deadly serious, it moves from creation through Jesus' life and death, to the witness of Mary Magdalene, in some twelve pages. The scene is set for what is to come. Mary, pondering on the events of the empty tomb, wonders what will happen when the disciples fashion the risen Jesus into a new Lord and Master, who rebukes Jews and conquers Gentiles, lording it over them as the Romans now lord 'over us'. She shudders: "Is there any way to rend this fabric, to let the

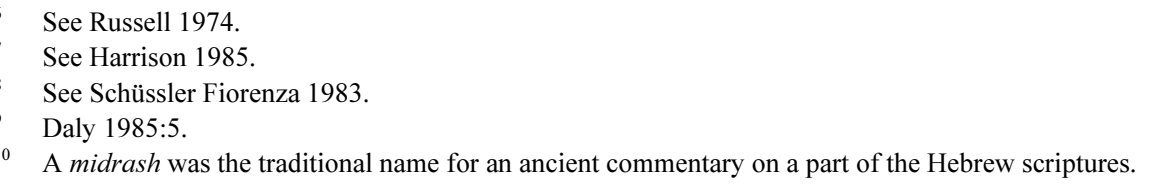


light of this other world shine through? Perhaps something of this other vision will still get through the distortion. Other people, even women like myself, will glimpse something of the true vision, and they will recognize me as their sister." 11 Ruether was about to "rend this fabric' and to offer her readers her version of the true vision.

An example of how she sets about critiquing and reconstructing Christian theology is found in her chapter entitled 'Anthropology: Humanity as male and female'. The question for feminist theology is "... how ... theological dualism of imago dei/fallen Adam connects with sexual duality, or humanity as male and female." ${ }^{12}$ Deeply rooted in Christian faith is the "... affirmation of the equivalence of maleness and femaleness in the image of God. This has never been denied, but is has tended to become obscured by a second tendency to correlate femaleness with the lower part of human nature in a hierarchal scheme of mind over body, reason over passions."13

Patriarchal anthropology has come perilously close to seeing women as the cause of sin in the world. From ancient to modern times, through the theology of Augustine, Aquinas, Luther and Barth, run the threads of patriarchal thinking. Augustine, the classical source of such views on women, believed that the male alone possessed the image of God normatively. Aquinas accepted a biological theory of women's inferiority and adopted the Aristotelian definition of woman as a 'misbegotten male'. ${ }^{14}$ Though the Reformation brought about some changes, patriarchal thinking continued to dominate Christian theology. "Women through the Fall and in punishment for the Fall lost her original equality and became inferior in mind and body. She is now, within fallen history, subjected to the male as her superior. This subjugation is not a sin against her, but her punishment for her sin. It is an expression of divine justice", writes Ruether. ${ }^{15}$ Barth subscribed to an order of creation. "God is sovereign over his Creation. The covenant of nature has not been annulled but reestablished in the covenant of grace by which Christ as head rules his people as obedient servants. Male and female, then, are necessarily ordered in a relation of those who lead and those who follow. Men and women should accept their own place in this order, the man humbly and the woman willingly." 16 Such, according to patriarchal anthropology, is the divinely ordered scheme of things.

Ruether then proceeds to identify alternative traditions in more egalitarian anthropologies including eschatological feminism, liberal feminism, romantic feminism, etc. These are also subjected to critical scrutiny. Ruether knows that an egalitarian and integrated theological anthropology has to overcome the divisions caused by dualistic world-views. This requires the integration of the private and public spheres in new relationships that are able to function in a new integrated social order. Such an order has to be just and, for Christians, the model for redeemed humanity is Jesus Christ. This means that the question of anthropology leads us theologically to the problem of Christology. Has traditional Christology in fact been redemptive for women or has it become a further tool for reinforcing female subjugation? These thoughts, and these questions may sound like old hat to the younger feminist theologians of today. Yet I have only to listen to a radio call-in programme for a short while to know that patriarchal anthropology, both socially and in the religious sphere, is alive and well in our context.

Underlying Ruether's writing is her passion for justice - justice in human relationships,

\footnotetext{
Ruether 1983:11.

Ruether 1983:93.

Ruether 1983:93.

Ruether 1983:95-96.

Ruether 1983:97.

6 Ruether 1983:98.
} 
social structures and religious practices. Her God is no patriarchal deity decreeing the subjugation of some and the superiority of others. Her God is not trapped in a male identity. For Ruether, God is both male and female, neither male nor female. In fact she states very clearly: "When the word Father is taken literally to mean that God is male and not female, represented by males and not females, then this word becomes idolatrous." ${ }^{\prime 7}$ She knows that we have no true name for the One who is the great 'I AM' and that to base anthropological notions on the idea of a male God and the maleness of the historical Jesus, is to miss Jesus' radicalizing hope for the reign of God on earth.

\section{Feminist Theological Methodology}

The first chapter in Sexism and God-talk sets out Ruether's methodology, sources and norms. It is worth quoting from at some length to establish her hermeneutical and methodological points of departure. The arguments are simple yet compelling. She begins: "What have been called the objective sources of theology; Scripture and tradition, are themselves codified collective human experience. Human experience is the starting point and the ending point of the hermeneutical circle."18 This is solid liberation theological talk. Then she states:

The uniqueness of feminist theology lies not in its use of the criterion of experience but rather in its use of women's experience, which has been almost entirely shut out of theological reflection in the past. Thus, the use of women's experience in feminist theology explodes as a critical force, exposing classical theology, including its codified traditions, as based on male experience rather than on universal human experience. ${ }^{19}$

Of interest here is the inclusiveness of Ruether's vision - she speaks of 'universal human experience' and is not interested in a system of thought that inverts discrimination. This however does not divert her from what she considers the critical principle of feminist theology - the promotion of the full humanity of women.

Whatever denies, diminishes or distorts the full humanity of women is, therefore, appraised as not redemptive. Theologically speaking, whatever diminishes or denies the full humanity of women must be presumed not to reflect the divine or authentic relation to the divine, or to reflect the authentic nature of things, or to be the message or work of an authentic redeemer or a community of redemption. ${ }^{20}$

She concedes that this principle is not new. What is new is the fact that women claim this principle for themselves. The distortion of the paradigm imago dei/Christ has to be named and countered. Women who have known denigration and discrimination must reach for "...a continually expanding definition of inclusive humanity - inclusive of both genders, inclusive or all social groups and races." 21 She suggests that women can do this by claiming the prophetic-liberating tradition of biblical faith as a norm through which to criticize the Bible and to enter the tradition of biblical faith that constantly criticizes and renews itself and its own vision This vision has four dominant themes: God's defense and vindication of the poor; the critique of dominant systems of power; the vision of a new age to come; and the critique of religion as ideology that sanctifies or justifies the dominant social order. ${ }^{22}$

\footnotetext{
Ruether 1983:66.

Ruether 1983:12.

Ruether 1983:13.

Ruether 1983:18-19.

Ruether 1983:20.

Ruether 1983:24.
} 


\section{Church and Ministry}

Much of Ruether's writing is devoted to reflecting on the paradoxical nature of the church's vision for ministry, and its reality. Like many Catholics concerned for justice, the Second Vatican Council was for Ruether an event rich with promise. In her words: "American Catholicism quickly took to the new freedom to question and renew the Church." ${ }^{23}$ Her earlier works ${ }^{24}$ reflect this enthusiasm.

Sadly, as far as women are concerned, the Council's intimations of change have dissipated over the intervening years. Despite her disappointment at the lack of change, Ruether has remained an influential voice in Catholic circles. "Frankly, if I hadn't been born into the Catholic Church I doubt I would have joined it", she remarked in an interview. ${ }^{25}$ Yet her abiding concern for reform in the Catholic Church continues. "To do that, I need to continue to identify as a Catholic, although I also function ecumenically and interreligiously, so it's not a limitation for me."26

The appearance of Women-Church heralded a new direction in Ruether's thinking on church and ministry. Instead of merely calling for reform, she detailed a blue print to deal with "...a moment of profound crisis and transmutation in the religion of Western Europe and North America, a crisis that is beginning to be felt in other parts of the world as well. This crisis is taking place particularly in Christianity..."27 Christian feminists could no longer wait for the institutional churches to reform themselves enough to meet the liturgical and faith needs of women. "Women in contemporary churches are suffering from linguistic deprivation and Eucharistic famine," she declared. ${ }^{28}$ Clearly, the historical church is not responding to the radical critique of women. Ruether has always been opposed to feminist separatism. In Women-Church she advocates a women church as an exodus church that embraces liminal religiosity. This is not an exile from patriarchy but an exodus to a new land. ${ }^{29}$ Clericalism, described as "...the separation of ministry from mutual interaction with community and its transformation into hierarchically ordered casts of clergy and laity," monopolizes teaching, sacramental action and administration turning the community into passive dependents. ${ }^{30}$ And clericalism is built on patriarchalism. It is time for something radically new.

Ruether provides guideposts for the journey - liturgies for women's pain, for rites of passage and for nature and history. The goal is to claim:

...the authentic mission of Christ, the true mission of the Church, the real agenda of our

Mother-Father God who comes to restore and not to destroy our humanity, who comes to ransom the captives and to reclaim the earth as our Promised Land. We are not in exile, but the Church is in exodus with us. God's Shekinah, Holy Wisdom, the Mother-face of

God has fled from the high thrones of patriarchy and has gone into exodus with us. ${ }^{31}$

No longer is Ruether calling on the prophets to purify the priests. This exodus is something new and different.

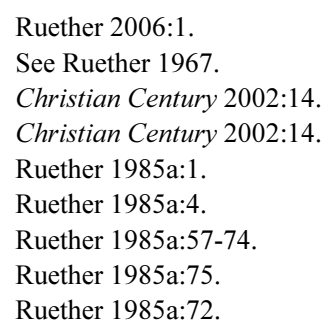


I agree with Rebecca Chopp ${ }^{32}$ that Ruether is right in seeking a new journey, a new way of asking questions. She is right when she finds that neither religious reformation nor secular revolution is a helpful guide. Something new is called for. Feminist theology can no longer merely seek equal access to justice. It now has to critique the ways in which "justice itself has been formed and understood, instituted, and contained. The point of feminist theology, accordingly, is not merely that women should have the right to name their experience, but that the very conception and ordering of terms such as experience, humanity, and universal rights can and must be questioned. ${ }^{33}$

\section{Assessing Ruether's Contributions to Feminist Theologies}

Assessing Ruether's contributions to feminist theologies requires more than a few condensed remarks. Her body of work is simply too extensive, too penetrating and too rich to do justice to in a short paper such as this. I will confine myself to a few critical reflections on issues that have cropped up in the categories in this discussion thus far.

\section{Experience as in 'Women's Experience'}

Let me lay my assumptions on the table. Feminist Practical Theology (or as I have referred to it previously, a Feminist Theology of Praxis) ${ }^{34}$ enquires into the relationship between acting and believing, between faith and praxis in the lives of women and their relationship to Christianity. Emphasis is laid on acting as the path to knowing, albeit not exclusively. ${ }^{3 .}$ Experience thus becomes a crucial resource for such theology. Douglas McGaughey writes: "Religion is driven by experience. If what religion professes does not resonate with one's experience, one then quickly backs away and looks for alternatives. Living religious traditions with cultural significance are able to survive because in some way they continue to speak to real time experience." ${ }^{36}$

Experience as a theological category needs to be explained and analyzed. Experience is a fundamental component of our relationship to the world we live in. Yet, when we limit our understanding of 'experience' to 'sense experience' we cannot claim that it is an exclusive criterion for truth. We mean more than 'sense experience' when we speak of reality. In the words of McGaughey "What we mean by 'experience' is in fact a set of convictions with respect to what we consider to be the truth of reality past, present and future... Experience is important with respect to our truth claims not because of its particular content but because of its universal structure. ${ }^{37}$ Problems arise when I validate what is in fact a 'sense experience' as a criterion for reality and truth. What makes something 'true' is its coherence with my cumulative experience. We are and should be continually testing our sense experience against its conformity or non-conformity with what we as individuals and communities have come to know to be reality. Thus, I cannot experience myself "...in and of itself but as a relational process, and, as a consequence, [I] must acknowledge another profound limit to experience as a criterion for determining 'reality'

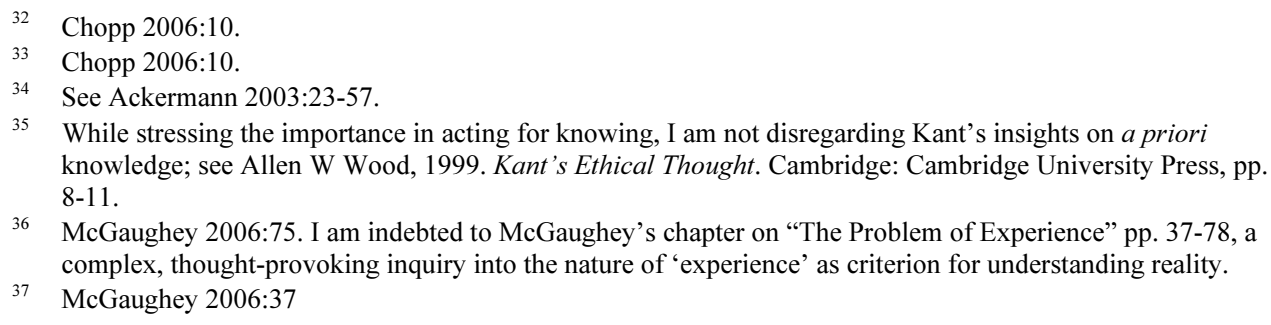

36 McGaughey 2006:75. I am indebted to McGaughey's chapter on “The Problem of Experience” pp. 37-78, a complex, thought-provoking inquiry into the nature of 'experience' as criterion for understanding reality.

37 McGaughey 2006:37 
and 'truth'. None of us know the inner world and its immaterial totality any more than we know the external physical world and its material totality. We are all products of situations that are not of our own choosing or construction." 38

'Action teaches us relationality', writes McGaughey, ${ }^{39}$ to which I can only say 'Amen!'

We act within given circumstances, for act we must. Our actions teach us that there are relational structures that function in ways that make it possible for us to act as we do in the world. In the light of these thoughts, Ruether's appeal to 'experience' is somewhat bald. It could be fleshed out further to deal with the multifaceted nature of this term. Perhaps she has not thought this necessary, since the connection between experience, relationships, action and faith permeates her theology and her life.

\section{The Prophetic-liberating Tradition}

Ruether insists that the prophetic tradition in Christianity is able to create shifts in the social location of religion, away from the ruling class, race and gender who justify their power as divinely ordained, to the side of the poor and the marginalized in society. "The prophet cries out against the injustices of the ruling elites, political, economic and religious. The prophet calls these elites to account for their betrayal of the religious vision of justice and mercy," she says. ${ }^{40}$ In the Hebrew tradition, this critique is directed against domination of the wealthy over the poor. In the New Testament this critical transformation is extended to envision a universal redemptive community not bound by an ethnic concept of election. True to her roots in liberation theology, Ruether continues: "Liberation theology today consists not only in a discovery of this prophetic, transformative side of tradition but also in its recontextualization or restatement for today. Speaking a prophetic word of God is not simply an exegesis of past texts but the midrashic retelling of the story of liberation in the contemporary context... Feminist theology involves, not simply an exegesis of past texts but a retelling of the story of redemption from women's experience."41

Elisabeth Schüssler Fiorenza has been vocal in her criticism of Ruether's hermeneutical approach. In her work In Memory of Her, Fiorenza finds Ruether's use of the prophetic messianic traditions of the bible unconvincing. Ruether concedes that this critical prophetic tradition did not explicitly apply "....itself to the women question either in the history of Israel or in Christianity". ${ }^{42}$ Ruether argues that, "In sum, it is not some particular statements about women's liberation, but rather the critical pattern of prophetic thought, that is the usable tradition for feminism in the Bible." "However, Fiorenza sees "neo-orthodox' implications in Ruether's hermeneutic proposal. "Not only does she draw a rather idealized picture of the biblical and prophetic traditions but also she overlooks the oppressive androcentric elements of these traditions", comments Fiorenza. ${ }^{44}$ Fiorenza's critique is based on the fact that Ruether does not analyze the classical prophetic tradition as an historical pattern but simply postulates it as a social-critical tradition in the interests of feminism. I doubt that Ruether, as a trained classical historian, is in fact unaware of the historical patterns in her hermeneutical approach. When Fiorenza further comments: “...but we are not told how and in what way feminist theology can transform this social-critical

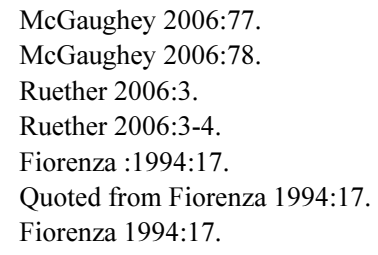


andocentric tradition into a feminist liberating tradition and use it to its own ends", ${ }^{45} \mathrm{I}$ am somewhat baffled. I can only conclude that this remark is time bound. For over twenty years Ruether has sought to do precisely this - to transform male-centred practices and traditions into ones that are liberating for women.

I find Rebecca Chopp's critique of Ruether's use of the prophetic-liberating tradition in conjunction with 'the full humanity of women', more convincing. ${ }^{46}$ Ruether's hermeneutic assumes an ideal construct of history, humanity and Christianity behind all the deformed ideas and doctrines that distort this ideal. This method is, according to Chopp, a variant of ideology critique in the humanistic tradition which does not match the vision contained in her later works. This later vision is "radically open, pragmatic in character and pluralistic in style, and ready to form radically new ways of being and doing. It involves, to paraphrase Ruether herself: 'Not merely wanting a piece of the pie, but creating a new recipe altogether'. ${ }^{47}$ Without doubt Ruether's thought has developed new insights given new contexts and challenges. Chopp, in my view, rightly finds that the humanistic method favoured by Ruether turns upon assumptions about a structure behind human history that is universal. These assumptions predispose us to speak of 'full humanity' as something independent of our concrete existence. This allows the term 'full humanity' to wander away from women's real concrete historical experiences. If we believe in a meta-historical structure we cannot explain women's complicity with patriarchy and we are unable to recognize places of subversion that exist in women's lives.

Chopp concludes: “...we can see the limitation of Ruether's methodological construction in the prophetic-liberating tradition of biblical faith, a molding of Christian theology into ideology critique that successfully raises consciousness, but is itself problematic due to failure of historical accuracy and its inability to identify already existing practices of subversion and transformation., 48

While I largely agree with Chopp's critique, such agreement needs qualification. I know how deep and ongoing Ruether's involvement is in issues of justice and transformation in Latin America, the Middle East and Asia. She is no ivory tower academic but an activist socialist feminist in the liberation mould.

\section{On Gender, Race and Ecumenism}

From 1965 to 1976 Ruether taught at Howard University, a black institution. "It was difficult to raise the question of gender there. It was an all-male faculty... Every time I raised the issue, I was accused of being racist. I realized that black women would have to raise these issues within the black community", she recalls. ${ }^{49}$ This early insight into the sensitivities of gender and race have stood her in good stead. From the very beginning Ruether, whose roots run deep in the Civil Rights Movement, has understood that there was no univocal 'woman'. Her work, together with that of the other early feminist pioneers, Russell and Harrison, has throughout used gender, race and class as interconnected structures that create multiple differences. Highly critical of the tendency among white people and men to universalize their experiences, Ruether's insights into the connection between racism and sexism are important for those of us working in a context where these issues are at the forefront of public discourse.

Fiorenza 1994:17.

46 Chopp 2006:10.

47 Chopp 2006:10.

48 Chopp 2006:11.

49 Hinton 2006:30. 
For many years Ruether has been at the vanguard of ecumenical and inter-religious dialogue. When asked what she thinks is the most significant development of feminism, she replied: "It is the contextualization of feminism across global communities: Women in Latin America; the Philippines; Africa; Christian, Jewish; Buddhist and Muslim. ${ }^{, 50}$ Ruether is keenly aware of the work of women in different contexts and has been willing to engage in dialogue, to debate and to learn from others. I find this one of her most appealing characteristics.

\section{Concluding Thoughts}

Ruether is no family or male-hating feminist. When asked in an interview whether parenting or grand-parenting had an impact on her scholarship, Ruether firmly replied: "Yes, it has a lot of impact" Parenting according to her keeps you grounded in "a lot of realities - not only in the whole work of bringing up little kids, but the questions that are important to young adults. ${ }^{, 51}$ She continues to explain that she is not saying that people ought to have their own children in order to be aware of younger people's experiences. Her concern is to help the next generation as she moves through the different stages of her life.

Ruether is a grounded woman who shares her activist concerns with her spouse Herman Ruether, ${ }^{52}$ a devoted grandmother who grows her own vegetables, a lover of nature, a member of Catholics for Free Choice - a pro-choice organization, a friend of Catholic thinkers such as Thomas Merton ${ }^{53}$ and Gregory Baum, and a feminist theologian who legitimates her writing through her activism and who draws on extra-canonical sources with scholarly skill.

Above all, Ruether's instincts for justice, her particular brand of scholarly activism that forges relationships across ethnic and racial boundaries, and her abiding concern for the liberation of all who experience oppression and discrimination, speak loudly into my context. Her methodological approach to social issues such as religious bigotry, sexism, church hierarchy, colonialism, militarism and ecological damage are as fresh and relevant today as they were when first propounded.

I am indebted to Ruether for her relentless pushing of boundaries. Perhaps more than any other feminist theologian, Rosemary Radford Ruether has continued to demonstrate that asking questions, the right questions, has enabled those who have come after her to rechart the journey towards a feminist religious revolution that will heal the split between mind and body, society and nature, and between males and females.

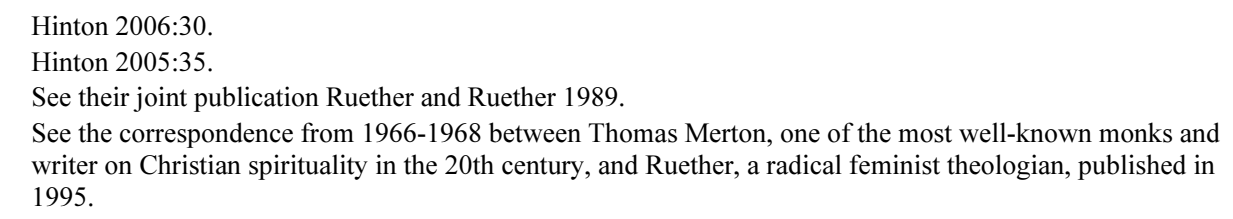




\section{BIBLIOGRAPHY}

Ackermann, Denise M 2003. After the Locusts: Letters from a Landscape of Faith. Grand Rapids: Eerdmans.

Christian Century May 22-29, 2002. "Ruether: Catholic reformer on Protestant soil".

Chopp Rebecca S 2006. "Seeing and naming the world anew: The works of Rosemary Radford Ruether". Religious Studies Review, 15:1. pp. 8-11.

Daly, Mary 1985. The Church and the Second Sex with the Feminist Postchristian Introduction and New Archaic Afterwords by the Author. Boston: Beacon Press.

Daly, Mary 1973. Beyond God the Father: Toward a Philosophy of Women's Liberation. Boston: Beacon Press.

Harrison, Beverly Wildung 1985. Making the Connections: Essays in Feminist Social Ethics, edited Carol S. Robb. Boston: Beacon Press.

Hinton, Rosemary 2006. "A legacy of inclusion: An interview with Rosemary Radford Ruether". Crosscurrents 52: 01, pp. 28-37.

McGaughey, Douglas R 2006. Religion before Dogma: Groundwork in Practical Theology. New York: T \& T Clark.

Ruether, Rosemary Radford 1967. The Church Against Itself. London: Sheed and Ward.

Ruether, Rosemary Radford 1983. Sexism and God-talk: Toward a Feminist Theology. Boston: Beacon Press.

Ruether, Rosemary Radford 1985a. Women-Church: Theology and Practice of Feminist Liturgical Communities. San Francisco: Harper and Row.

Ruether, Rosemary Radford 1985b. To Change the World: Christology and Cultural Criticism. New York: Crossroad.

Ruether, Rosemary Radford 1989. Disputed Questions: On Being a Christian. Maryknoll: Orbis Books.

Ruether, Rosemary Radford 1992. Gaia and God: An Ecofeminist Theology of Earth Healing. San Francisco: Harper San Francisco.

Ruether, Rosemary Radford 2003. Gregory of Nazianzus: Rhetor and Philosopher. Reprint Lima, Ohio: Academic Renewal Press.

Ruether, Rosemary Radford 2006. "The development of my theology". Religious Studies Review, 15:01, pp. 1-11.

Ruether, Rosemary Radford and Ruether, Herman J 1989. The Wrath of Jonah: The Crisis of Religious Nationalism in the Israeli-Palestinian Conflict. San Francisco: Harper \& Row.

Russell, Letty 1974. Human Liberation in a Feminist Perspective - A Theology. Philadelphia: The Westminster Press.

Schüssler Fiorenza, Elisabeth 1983. In Memory of Her: A Feminist Theological Reconstruction of Christian Origins. New York: Crossroad.

Tardiff, Mary (ed.) 1995. At Home in the World: The Letters of Thomas Merton and Rosemary Radford Ruether. Maryknoll: Orbis Books. 